\title{
Quality University Education Through Conducive Classroom Learning Environment
}

* Dr. Nasir Shaheen: Assistant Professor/Director QEC

** Dr. Nasir Ahmad: Assistant Professor

*** Dr. Rehmat Shah: Assistant Professor

\begin{abstract}
Quality university education is the central aspiration of universities in the $21^{\text {st }}$ century where different dimensions are explore as starting point including classroom learning environment. This classroom learning environment can boost or hinder students' learning which covers the physical and psychological dimension shaving significant effects on classroom teaching learning process at university level. Promoting quality education therefore needs; supportive classroom environment, students' confidence building, provision of learning facilities, its utilization, self-developed code of conduct and sense of responsibility among the stakeholders. This study explored students and teachers views about quality education through conducive' classroom learning environment at university level following explanatory research design with a questionnaire and interview tools. The findings revealed that teachers took the learning responsibilities of students, impose external code of conduct for classroom business, rare utilization of classroom learning resources and scarcity of some important instructional materials for teaching in classroom. Therefore, it was recommended, that teachers may accept students' potential, trust in them, respect their view point by engineering critical and creative thinking through authentic instructional approach.
\end{abstract}

Keywords: Quality Education; Learning Environment; Confidence; Creativity; Authentic

\section{Introduction}

The provision of quality education is the ultimate goals of universities. They are therefore, investing in different aspects of education including, physical facilities, faculty professional development, psychological wellbeing of faculty and students and on overall learning environment within the campus learning of students (Virmani, 2006). Further, to ensure the quality of education the universities on the directives of Higher Education Commission (HEC) of Pakistan has established Quality Enhancement Cells (QEC) in universities to

\footnotetext{
* University of Swat Email: nasirshaheen@ uswat.edu.pk

** Centre for Education and Staff Traning, University of Swat Email: nasir_cupid@ uswat.edu.pk

*** Virtual University Lahore
} 
evaluate these aspects of teaching learning processes in universities (Usmani, Khatoon, Shammot, \& Zamil, 2012). Researchers and experts viewed quality education as authentic education which concentrates on creative abilities, critical thinking, confidence, and other lifelong learning skills among students. That's why it's important to support authentic education through promoting conducive classroom learning environment (Osakwe, 2014).

A classroom environment is the combination of physical, psychological and instructional setting done by a formal educational institution for the effective implementation of the instructional plan which promotes learning of students (Taylor, Fraser, \& Fisher, 1997). The development of pro-learning environment is the joint responsibility of students, teachers and head of the educational institutions. Head of the institution as educational leaders provides institutional vision, devise educational strategies, design plans and mobilize the required resources taking into consideration all stakeholders of the process. Further, teachers along with students ensure the actual utilization of these provisions and reach obtain the institutional educational targets (Hue, \& Li, 2008).

Furthermore, teachers and students are also responsible to create the environment that boosts the teaching learning process. On one side teacher has a crucial role of creating conducive classroom environment taking into consideration the students and the educational leadership through fulfill all the resources required for the wellbeing of students both psychologically and physically. On the other hand, he/she is also responsible for training and preparing the students for their classroom active roles (Fiedler, \& Pata, 2010). This process starts with students' orientation to course work, semester rules regulations, institutional vision and mission and academic standards, proceeds through academic skills development, collaborative, creative and critical thinking skills development and ends at the achievement of academic excellence in the form of university vision and mission. Throughout this journey, teachers required support from the educational leader in term of physical resources, instructional materials, psychological backup and continue professional development opportunities which enable him to perform his duty in an engineer manner (Hue, \& Li, 2008). Likewise, teachers also need students with required knowledge, skills and attitude that they are required for entrance to the next level. Furthermore, the teacher along with students and educational leader design the instructional plan in the light of national curriculum, international trends and social demands of the society. Teachers should also play their critical role in solving the learning related issues of the students through cooperative, collaborative and authentic pedagogical approaches (Hussain, Ahmad, \& Khan, 2015). Students with 
learning difficulties needs more attention and opportunities from teachers and overall learning setting where a conducive classroom learning environment can play a leading role. As it motivate the slow learner and provide them the opportunity to progress according to their learning pace (Moos, 1979).

There are certain factors that affect students' learning including teaching methodologies, classroom environment, students' learning styles, subject matter, educational facilities and its utilization. All these factors have either related to students and to teachers or to the educational management of university. But Fraser and Pickett viewed classroom environment as student-teachers shared perspective. Therefore, it is the utmost one which can significantly contribute into the quality education of students. Different researchers explained this construct differently, like Fraser and Pickett (2010) a classroom environment is a combination of different elements and factors such as classroom seating, students' teacher interactions, students' classroom behavior, peers interactions and other basic instructional aids. Therefore, a teacher should start the class with high expectation and for having positive classroom environment the involvement of teacher and students are necessary.

Further, for having a conducive classroom environment classroom meetings should be arranged for the students to discuss their problems freely and there should be positive relationships among students and teachers for obtaining developing good results (Findley, \& Varble, 2006). Likewise, Learning depends on the nature and quality of reinforcement provided to learner acquainted with progress of learning in terms of strength and weaknesses. The results are influenced by nature and quality of the methods and techniques employed for teaching and learning of the particular content, subject matter or learning experiences. The factors that can affect the classroom environment is lack of motivation and problems bring by students from home. There should be mutual respect and social support among teacher and students along with clear expactations teacher for mentaining healthy classroom environemt (Nelsen,Lott, \& Glenn, 2000).

There are certain tools for classroom environment. In classroom environment it is important to apply the gathered information resulting in students successs and creating a better school improvemt plan. The seating position, design, privacy and noise also play an important role in shaping classroom environment. The students with higher self efficacy gains more than students wit low self efficacy. Likewise, teachers should arrange classrooom meetings. These classroom meetings are of 3 types; open ended meetings, problem solving meetings and educational diagnostic meetings. The nature of meeting is dependent on the 
nature of problems and thus the respondents will also different with a different agenda (Fraser, 1982). There are different factors that affect students' learning it includes school culture, environment, teaching methodology, students' learning style and some others. Teachers are required training and instructional aids necessary for teaching. It would be helpful to the researcher to have the knowledge about how to promote conducive learning environment for learning. The study would also help the researcher to identify the problems in the classroom and how to create effective classroom environment for students learning. This would help the researcher to investigate the current learning environment for students. The learning takes place in the presence of all physical and psychological factors so are the physical equipment's are there for the learning of students so are the physical equipment's are provided, is the learning takes place in the classroom at secondary level? Is the physical resources are available in classroom at secondary level? Is the learning takes place according to the mental level and interest of students?

\section{Research Problem}

Everyone needs quality education and therefore, educational institutions (universities) do invest in it from different perspectives. The investment in conducive learning environment has a directs output in the form of quality graduates who are prepared to the practical life challenges and thus can effectively put their contribution into the overall development of country in particular and in the world generally. Therefore, the current study intended to explore the mechanisms that how conducive classroom learning environment can leads towards quality university education.

\section{Research Objectives}

This research study has targeted the following research objectives;

1. To explore faculty perceptions about quality education

2. To investigate faculty perceptions about conducive classroom learning environment

a. To reconnoitre faculty perceptions about quality education through conducive classroom learning environment

\section{Research Questions}

The researchers in this study attempted to answer the following research questions;

1. How university faculty perceived quality education?

2. What university faculty mean by conducive classroom learning environment?

3. What are the university faculty perceptions about quality education through conducive classroom learning environment? 


\section{Research Methodology}

In Pakistan currently there are more than 200 hundred public and private sector universities range from general to medical, engineering, agriculture, law, medicines, Information and Communication Technology universities and nearly all these universities have QECs which supervises the teaching learning processes to ensure the quality of students learning. In these universities, this gigantic task of quality education is dependent on teaching staff who strives their best to prepare the students follow high level of quality in teaching, learning and assessment processes. Therefore, the researchers have selected the students and faculty members of seven universities to investigate the research problem selected for the study in hand.

Therefore, researchers adopted mixed method explanatory research design with a questionnaire and interview protocols for data collection from students and faculty members of these universities. A total 671 faculty members constituted the population from which through multi-stage sampling techniques a total of 360 respondents were placed in study sample group. Furthermore, a total of 433 students were also selected from 21776 students through simple random sampling techniques. A questionnaire was developed which was validated through seven $\mathrm{PhD}$ Doctors and were pilot tested on 31 teachers and 69 students who were excluded from the sample group. The reliability co-efficient of the questionnaire was $\alpha .79$. Similarly, a total of 11 teachers were interviewed through interview protocols to confirm the quantitative results of the study.

After the finalization of research questionnaire it was used for data collected from the sample group through personal visited, Google form and through Pakistan postal service and interview from teachers were conducted through face to face interactions. All the collected data were analyzed by Statistical Package for Social Sciences (SPSS) through applying the mean scores, Standard deviation independent sample t test and Pearson co-relation. Further the interview data were descriptively analyzed.

\section{Analysis and Interpretation}

Collected data were analysis through descriptive and inferential statistics and the results were presented in the following tables and interpretations;

\section{1- Teachers and Students views about quality education and classroom learning environment}




\begin{tabular}{|c|c|c|c|c|c|c|}
\hline Quality Education & \multicolumn{2}{|c|}{ Teachers } & \multicolumn{2}{|c|}{ Students } & \multirow[t]{2}{*}{ t value } & \multirow[t]{2}{*}{ Sig } \\
\hline & Mean & SD & Mean & SD & & \\
\hline a. Effective and efficient learning & 3.89 & 1.99 & 3.92 & 1.85 & .851 & .713 \\
\hline $\begin{array}{l}\text { b. Skill based and experiential } \\
\text { opportunities }\end{array}$ & 2.10 & 1.08 & 2.57 & 1.18 & 1.63 & .072 \\
\hline c. Creative and critical thinking & 2.35 & .877 & 3.51 & .751 & 3.28 & .000 \\
\hline $\begin{array}{l}\text { d. Collaborative and authentic } \\
\text { approaches }\end{array}$ & 3.87 & 1.441 & 3.91 & 1.32 & .655 & .699 \\
\hline $\begin{array}{l}\text { e. Aspiring for relevant and lifelong } \\
\text { skills }\end{array}$ & 2.19 & 1.071 & 3.87 & 1.82 & 2.11 & .04 \\
\hline
\end{tabular}

\section{Classroom Learning Environment}

\begin{tabular}{|c|c|c|c|c|c|c|c|}
\hline a. & Classroom code of conduct & 4.01 & .872 & 4.17 & .921 & .811 & .314 \\
\hline b. & $\begin{array}{l}\text { Learning facilities and its } \\
\text { utilization }\end{array}$ & 4.07 & .913 & 4.05 & .901 & .561 & .813 \\
\hline c. & $\begin{array}{l}\text { Mutual trust and academic } \\
\text { relationships }\end{array}$ & 4.72 & .911 & 4.51 & .881 & .567 & .751 \\
\hline d. & $\begin{array}{l}\text { Cooperative and collaborative } \\
\text { learning }\end{array}$ & 3.76 & .753 & 4.07 & 1.87 & 3.10 & .004 \\
\hline e. & Seating and subject requirements & 4.17 & .851 & 4.10 & 1.05 & .891 & .319 \\
\hline
\end{tabular}

Teachers and students have some differences of opinions about quality education particularly from authentic learning, creativity and critical thinking and aspiring for lifelong skills of students in the prevailing education for students in Pakistani universities. the teachers considered that on the above mentioned areas university education is not meeting the standards of quality education as it is not preparing the students to real life demands. Furthermore, they considered the current education as effective and efficient where collaborative and authentic approaches are adopted by teachers but on the other hand with these perceptions the students were not agreed.

On the second construct most of the teachers and students have similar kind of opinions about the classroom learning environment at university level. The university's classrooms do follow code of conduct for classroom management, most of the required instructional facilities are available and these are utilized by the teachers and students during the teaching learning process. But still there were differences of opinion between teachers and students on cooperative and collaborative approaches in classroom teaching learning 
processes. Both the groups were agreed that they have academic relationships and mutual trust. Furthermore, they are also agreed that the classroom seating and subject related required facilities are available in classroom to make the teaching learning process effective and efficient.

All these results were further proved by the interview data from teachers who viewed that quality education parameter needs more attention and investment in term of faculty professional development, changes in curriculum (subject matter) and special focus on the lifelong and experiential learning through authentic pedagogical practices at classroom level. Similarly, classroom learning environment is not that much conducive and there is lack of trust and mutual understanding between students and teachers because of the workload, administrative matters and students' low level skills at the time of entry to university education are significant reasons responsible for their low academic achievement at university level that also question the quality of university education internationally and regionally.

2- Relation of quality education and classroom learning environment (Teachers \& Students)

\begin{tabular}{llll}
\hline Respondents & Constructs & r value & Sig \\
\hline Teachers & Quality Education & .544 & .000 \\
& Classroom Learning environment & & \\
\multirow{2}{*}{ Students } & Quality Education & .671 & .000 \\
& Classroom Learning environment & & \\
\hline
\end{tabular}

A significant positive correlation was measured from teachers' perspectives between the constructs of quality education and classroom learning environment as shown by the r value .544 which is significant at .000 . Similarly, a significant high correlation was found between the constructs of quality education and classroom learning environment from students' perspective as reflected by $\mathrm{r}$ value .671 with sig value .000 . These results revealed that there are positive correlations between quality education and classroom learning environment. It also showed that classroom learning environment provides base for quality education.

In addition to the above the interview data revealed that quality education could be started at classroom level where the teacher shoulder the responsibilities of making the learning relevant to real life situations. Teachers also can make the differences from the point of view that they can mobilize the curriculum change and can lead the process from the front line. 


\section{Conclusions}

Quality education is a relative term which is associated with numerous issues and questions but still it's the relevance and real life situations that make it important from quality concerns in education. In this study it was concluded that teachers and students were agreed with the effectiveness and efficient learning at classroom. Further they were also agreed that collaborative and authentic learning approaches are indispensible for quality education. However differences were found on the matters of experiential, creative and critical thinking of students which are important for ensuring the quality education.

The study also concluded that teachers and students were agreed on the constructs of classroom learning environment. They were agreed that a code of conduct do exist in the classroom which govern the classroom affairs and that a close positive and interactive academic relationship along with mutual trust is also established between teachers and students.

Similarly, both the groups were agreed on the effectiveness of classroom seating and subject matter related materials in classroom. Overall it was concluded that the classroom environment was found effective for teachers learning process.

But from interview data it was concluded that classroom code of conduct was imposed externally as these are pre-determine rule regulations where students' have no say. Further, it was also concluded from interview results that students feeling hesitation while discussing their academic problems with teachers and that students were not involved in planning the instructions including design instructional materials for teachers which reflects that teachers own the responsibility of students' learning and that they don't trust on students' capabilities.

\section{Recommendations}

Laconically, it was recommended that at university learning students are mature enough to be included in decision making process at classroom level which will result in attaining the desired targets of classroom learning.

It was also recommended that teachers may accept students' potential and they may be involve in the designing classroom learning process, developing code of conduct for classroom affairs through encouraging their participation in teaching learning process.

Further teachers were recommended that students may provide ample opportunities of hands-on practices for experiential learning and they may connect classroom learning to real life situations. Likewise, fixed classroom seating doesn't fulfill the demands of all type of 
subjects, therefore; classroom seating may be adjusted so that it may be easily switch from one style to another to make learning effective and to ensure quality education at university level.

\section{References}

Fiedler, S., \& Pata, K. (2010).Distributed learning environments and social software: In search for a framework of design. In Social computing: Concepts, methodologies, tools, and applications (pp. 403-416). IGI Global.

Findley, B., \& Varble, D. (2006). Creating a conducive classroom environment: Classroom management is the key. College Teaching Methods \& Styles Journal, 2(3), 1-6.

Fraser, B. J. (1982). Differences between student and teacher perceptions of actual and preferred classroom learning environment. Educational Evaluation and Policy Analysis, 4(4), 511-519.

Hue, M. T., \& Li, W. S. (2008). Classroom management: Creating a positive learning environment (Vol. 1). Hong Kong University Press.

Hussain, S., Ahmad, N., \& Khan, F. N. (2015). The Effects Of Authentic Pedagogical Practices On Students' Educational Performances and Retention Power. Pakistan Journal of Education, 30 (II), 47-62.

Moos, R. H. (1979). Evaluating educational environments. San Francisco: Jossey-Bass.

Nelsen, J., Lott, L., \& Glenn, H. S. (2000). Positive discipline in the classroom: Developing mutual respect, cooperation, and responsibility in your classroom. Three Rivers Press.

Osakwe, R. N. (2014). Classroom management: A tool for achieving quality secondary school education in Nigeria. International Journal of Education, 6(2), 58.

Pickett, L., \& Fraser, B. (2010). Creating and assessing positive classroom learning environments. Childhood Education, 86(5), 321-326.

Taylor, P. C., Fraser, B. J., \& Fisher, D. L. (1997).Monitoring constructivist classroom learning environments. International journal of educational research, 27(4), 293-302.

Usmani, M. A. W., Khatoon, S., Shammot, M. M., \& Zamil, A. M. (2012). Towards a Network of Quality Assurance in Higher Education: A Pakistani Model. Archives Des Sciences, 65(7), 224-229.

Virmani, A. (2006). Lessons Of Government Failure: Public Goods Provision And Quality of Public Investment,". Planning Commission Working Paper, (2). 